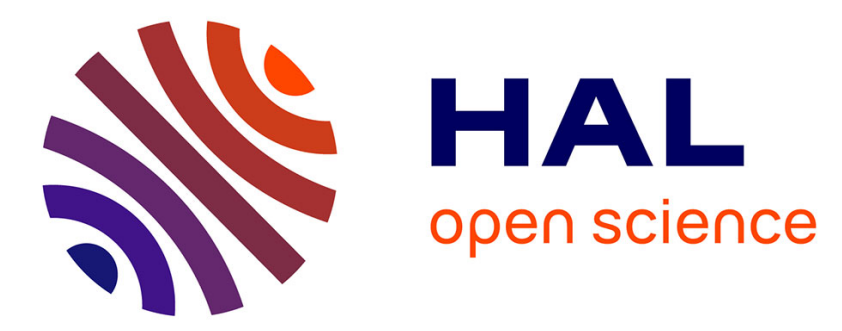

\title{
Carbazole-based material: synthesis, characterization, and application as hole transporting material in perovskite solar cells
}

Diego Magaldi, Maria Ulfa, Sébastien Péralta, Fabrice Goubard, Thierry Pauporté, Thanh-Tuân Bui

\section{To cite this version:}

Diego Magaldi, Maria Ulfa, Sébastien Péralta, Fabrice Goubard, Thierry Pauporté, et al.. Carbazolebased material: synthesis, characterization, and application as hole transporting material in perovskite solar cells. Journal of Materials Science: Materials in Electronics, 2020, 10.1007/s10854-020-04021-2 . hal-02999913

\section{HAL Id: hal-02999913 https://hal.science/hal-02999913}

Submitted on 11 Nov 2020

HAL is a multi-disciplinary open access archive for the deposit and dissemination of scientific research documents, whether they are published or not. The documents may come from teaching and research institutions in France or abroad, or from public or private research centers.
L'archive ouverte pluridisciplinaire HAL, est destinée au dépôt et à la diffusion de documents scientifiques de niveau recherche, publiés ou non, émanant des établissements d'enseignement et de recherche français ou étrangers, des laboratoires publics ou privés. 
Please cite this article as:

Diego Magaldi, ${ }^{1}$ Maria Ulfa, ${ }^{2}$ Sébastien Péralta, ${ }^{1}$ Fabrice Goubard, ${ }^{1}$ Thierry Pauporté, ${ }^{2}$ Thanh-Tuân Bui ${ }^{1 *}$

\section{Carbazole-based material: Synthesis, Characterization and Application as hole transporting material in perovskite solar cells.}

J Mater Sci: Mater Electron (2020). DOI:10.1007/s10854-020-04021-2

${ }^{1}$ CY Cergy Paris Université, LPPI, F-95000 Cergy, France.

${ }^{2}$ Chimie ParisTech, PSL Research University, CNRS, Institut de Recherche de Chimie Paris (IRCPUMR8247), 11 rue P. et M. Curie, F-75005 Paris, France

*Corresponding author: tbui@cyu.fr (T.-T. B.)

\section{Abstract}

The synthesis and characterization of a novel oligomeric cyclic carbazole-based material (PCz1) for an application as hole transporter (HTM) in hybrid perovskite photovoltaic devices is reported. Its preliminary application in $\mathrm{Cs}_{0.08} \mathrm{FA}_{0.80} \mathrm{MA}_{0.12} \mathrm{~Pb}\left(\mathrm{l}_{0.88} \mathrm{Br}_{0.12}\right)_{3}$ mixed perovskite solar cell (PSC) leads to a device power conversion efficiency of $18.04 \%$ which is comparable to that of the Spiro-OMeTAD reference cells (17.94 \%). In addition, the novel HTM is proved to act as a good barrier and protect satisfactorily the perovskite surface giving highly stable PSC devices.

\section{Keywords}

Hole transporting materials; perovskite solar cell; carbazole; arylamine; oligomer

\section{Introduction}

Generally the active component of a perovskite solar cell (PSC), composed of an inorganic or hybrid perovskite material layer acting as the light absorber, is sandwiched between two charge transporting layers. The hole transporting layer $(\mathrm{HTL})$ extract holes at the $\mathrm{HTL} /$ perovskite interface and transport them towards the cathode while the electron transporting layer (ETL) permits the electrons extraction and transportation. It has been clearly established that the incorporation of HTL and ETL in 
PSC's device structure is highly important for the devices to be efficient and stable.[1] In this context, accurate design of HTL is of major interest. The HTL is usually made from a single hole transporting material (HTM). However, in some case a mixture of different HTM can be employed.[2] Hole transporting capacity is key for achieving high photovoltaic efficiency. Usually, some additives and/or chemical dopants are incorporated to increase the charge transport capacity of the organic semiconductors. In addition, the $\mathrm{E}_{\text {Hомо }}$ and $\mathrm{E}_{\mathrm{LUMO}}$ of the HTM must be compatible with the valence band maximum and conduction band minimum of the perovskite in order to provide the suitable driving force for charge transfer and block the electrons back transfer. Other researched characteristics include excellent thermal, morphological and photochemical stability, and good hydrophobic properties to protect the perovskite materials from moisture. The hole transporter can be either inorganic, organic or coordination compounds. $[3,4]$ Organic HTMs are sub-classified into molecular and polymeric materials. If molecular HTMs have well-defined molecular weight and structure and good synthetic reproducibility, the polymeric counterparts have important advantages in terms of processability, thermal and mechanical stability, and higher intrinsic hole mobility.[5] Among various organic HTM, carbazole-based HTMs is of particular interest thanks to their unique features suitable for developing photovoltaic materials.[6,7,16-25,8-15] We have previously exploited carbazole platform to design HTMs for solidstate DSSCs[9] and PSCs.[6,11,26] Bulky dendritic carbazole compound, which take the best of both molecular and polymeric HTMs features, has been proved to be an effective design strategy, giving improved PSCs in terms of the stability.[6,7] Herein a new oligomeric cyclic carbazole based HTM (Scheme 1) is proposed which provide device performance comparable to that of Spiro-OMeTAD and also markedly improves the device stability.
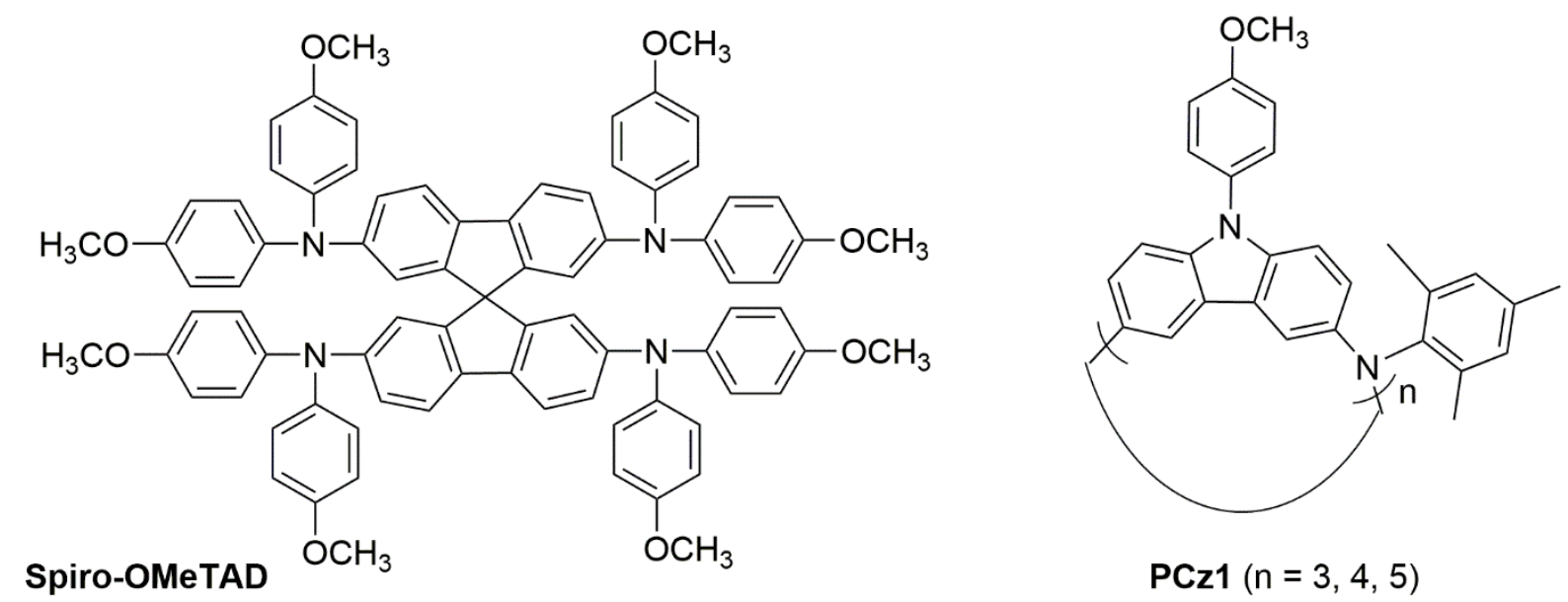

Scheme 1. Molecular structures of investigated HTMS 
The presence of the 2,4,6-trimethylaniline unit as hydrophobic and structuring agent is expected to favor the nano-structuration in HTM inducing a better conductivity in PSC device. This singularity has already been observed with PTAA as HTM in PSCs.[27] Moreover, methyl groups decrease the arrangement disorder between molecules due to lower repulsion of methyl groups and benzene rings, favoring also the carrier mobility within the HTM.[28]

\section{Results and discussion}

\subsection{Material synthesis}

PCz1 was synthetized in three steps as detailed in Scheme 2. Briefly, N-(4methoxyphenyl)carbazole (1) was produced by a copper-catalysed Ullmann amination reaction. 1 was then treated by $\mathrm{N}$-bromosuccinimide giving 3,6-dibromo- $N$-(4-methoxyphenyl)carbazole (2).
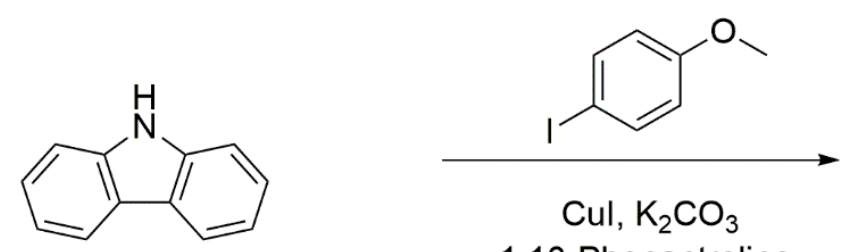

Cul, $\mathrm{K}_{2} \mathrm{CO}_{3}$ 1,10-Phenantroline, $\mathrm{DMF}, 115^{\circ} \mathrm{C}$<smiles>COc1ccc(-n2c3ccccc3c3ccccc32)cc1</smiles>
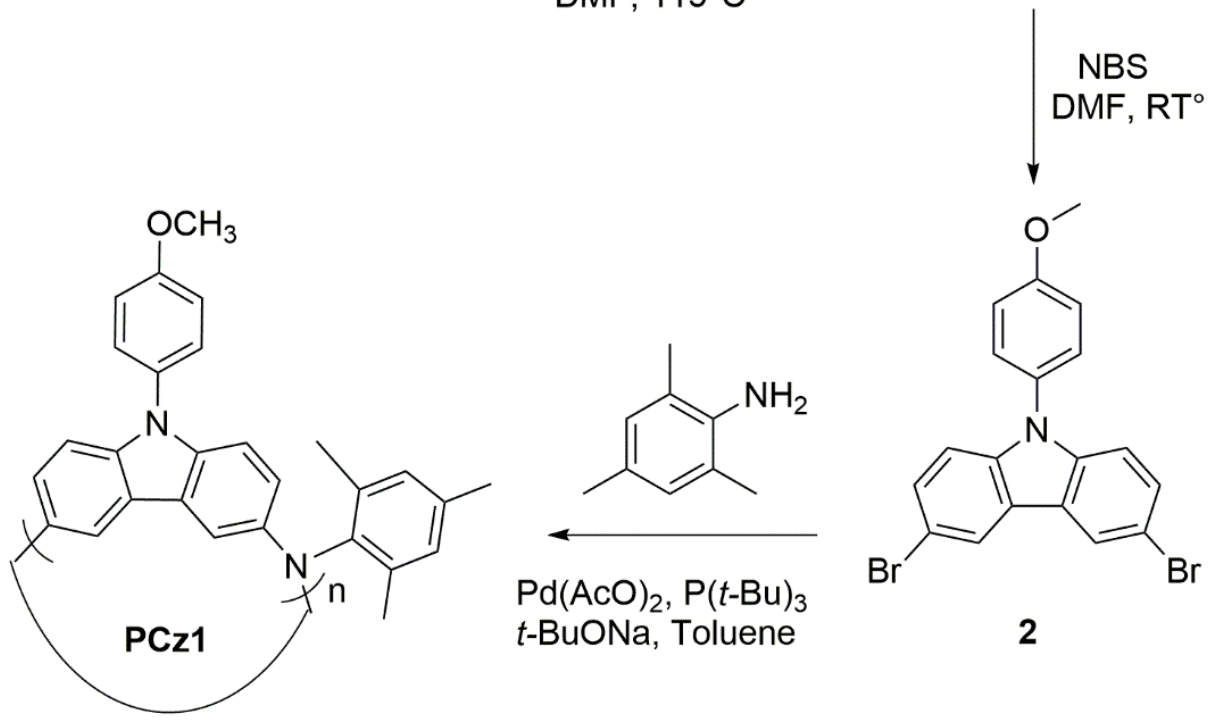

$t$-BuONa, Toluene

Scheme 2. Synthesis of carbazole-based HTM PCz1

The final step consisted in a Pd-catalysed Buchwald Hartwig amination reaction. The treatment of 2 with an equimolar equivalence of 2,4,6-triphenylaniline gave an inseparable mixture of oligomers. MALDI-TOF 
MS analysis suggests clearly the co-existence of tris, tetra and penta co-oligomers in the mixture. The theoretical DFT calculations have confirmed the presence of a mixture of different oligomers in the mixture. The obtained materials presented a good solubility in organic solvents commonly used for the deposition of HTM such as chlorobenzene, toluene, chloroform, etc. We then directly characterized this mixture for the purpose of application as HTM in PSCS.

\subsection{Material Characterization}

\section{DFT Calculation}

These oligomers (tris, tetra and penta cyclic compounds) were investigated by DFT. The optimized geometries and energies of the tetra-oligomer, the most abundant one, are given in the Figure 1 and the data for the other two compounds are provided in the ESI (Figures S1, S2 and Table S1).

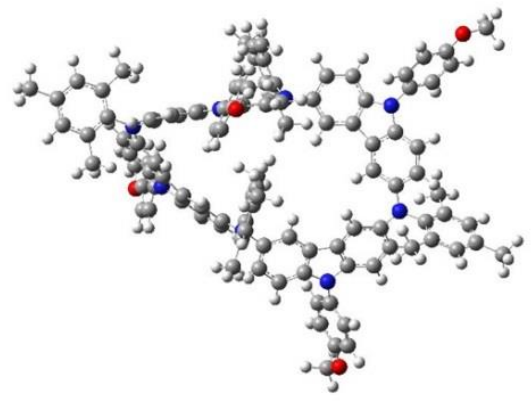

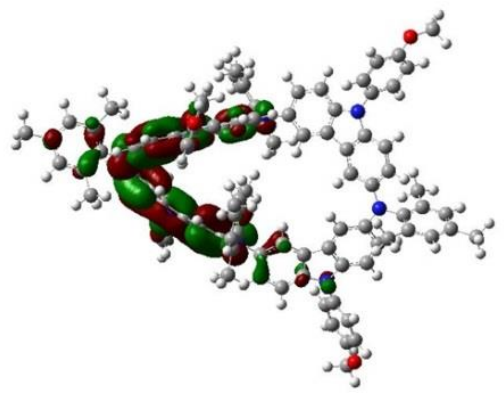

HOMO

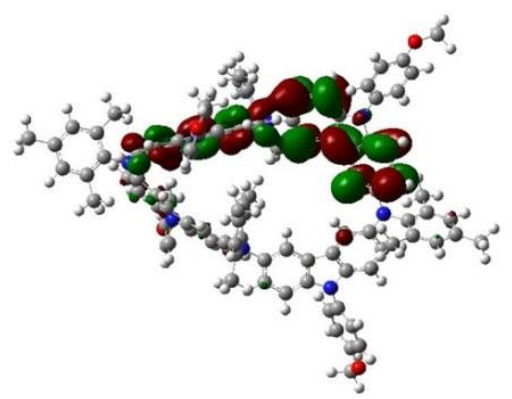

LUMO

Figure 1. Optimized geometry and HOMO LUMO distribution of the tetra-oligomer.

As can be observed for PCz1, their HOMO and LUMO were partially developed over the whole molecular structure. This is explained by the fact that the cyclic compounds have a distorted structure. All oligomers have nearly an identical optimized energy per repeated unit (Table S1, ESI). While the ELUmo levels are nearly identical for all the compounds, the tris oligomer has a deeper HOMO level compared to the tetra and penta oligomers.

\section{Thermal, morphological and optoelectrochemical properties}

PCz1 showed a good thermal stability with a $T_{d}>340^{\circ} \mathrm{C}$ (Figure 2a) which is high enough for the applications in PSC. No melting point was observed until $280^{\circ} \mathrm{C}$ in differential scanning calorimetry (DSC) analysis (data not shown) suggesting that the material obtained is amorphous. However, the DSC curves revealed a complex behaviour due to the presence of different oligomers. 
(a)

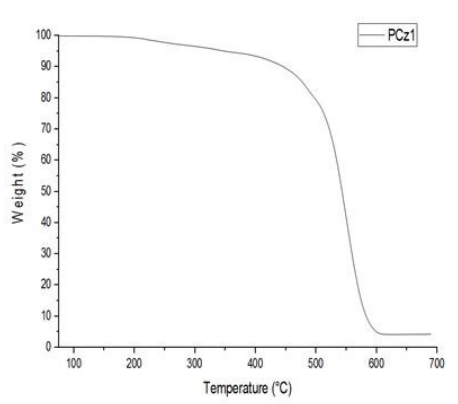

(b)

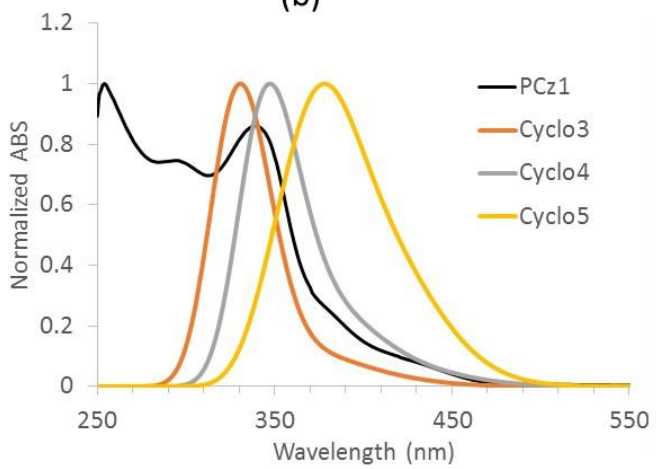

(c)

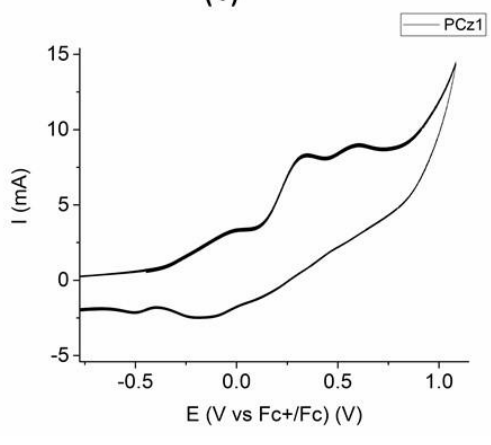

Figure 2. (a) TGA curve of PCz1. (b) Absorbance of PCz1 in dichloromethane and calculated spectra for tris, tetra and penta cyclic molecules (CycloN, N=3, 4 and 5). (c) Cyclic voltammetry of PCz1 in dichloromethane.

The absorption properties of the PCz1 mixture recorded in dilute dichloromethane solution is shown in Figure $2 \mathrm{~b}$. It presents a strong absorption band centered at $338 \mathrm{~nm}$ and shoulders at lower energy attributed to an extended conjugated system including carbazole/tertiary amine ones. The simulated absorption spectra in $\mathrm{CH}_{2} \mathrm{Cl}_{2}$ of different oligomers are also displayed in Figure $2 \mathrm{~b}$ with the maximum absorption wavelength are 331, 347 and $378 \mathrm{~nm}$ for tris, tetra and penta cyclic molecules, respectively. This is in good accordance with the assumption that PCz1 is a mixture composed mainly of these cyclic oligomers. PCz1 mainly absorbs in the UV spectral domain, which will not cause a competitive absorption effect with the perovskite materials. The optical bandgap $\left(E_{g}=2.74 \mathrm{eV}\right)$ is calculated from the absorption onset wavelength (Figure $2 \mathrm{~b}, 460 \mathrm{~nm}$ ). This value is somewhat smaller than that of the Spiro-OMeTAD (3.00 eV).[9] Cyclic voltammetry (CV) was employed to investigate the redox behavior of PCz1 in dilute solution (Figure 2c). The cyclic voltammogram of PCz1 shows multiple oxidation processes. The first reversible oxidation could be attributed to the formation of radical cation of the carbazole moiety. PCz1 has an oxidation onset potential of $-0.36 \mathrm{~V}$ versus $\mathrm{Fc} / \mathrm{Fc}^{+}$, which is lower than that of Spiro-OMeTAD ($0.11 \mathrm{~V} / \mathrm{Fc} / \mathrm{Fc}^{+}$) measured under the same conditions.[9] These redox potentials were then employed to estimate their Eномо and ELUmo in the solid state by using the ferrocene ionization energy as the standard. $\mathrm{E}_{\text {Hомо }}$ was estimated from the first oxidation potential while $\mathrm{E}_{\mathrm{LUm}}$ was estimated from the $\mathrm{E}_{\text {Hомо }}$ and $\mathrm{E}_{\mathrm{g}}$. The Еномо values of PCz1 and Spiro-OMeTAD are - $4.74 \mathrm{eV}$ and $-4.99 \mathrm{eV}$, respectively, assuming that the ionization potential of Ferrocene is $5.1 \mathrm{eV}$ versus vacuum. The corresponding ELUmo are -2.0 and -1.99 eV, respectively. The $\mathrm{E}_{\text {Hомо }}$ level of PCz1 is thus higher than that of Spiro-OMeTAD meanwhile both compounds have very similar ELumo levels. This suggests that, energetically, PCz1 could be suitable as an alternative HTM to Spiro-OMeTAD. 
In order to improve the device stability against moisture in real operation, the HTM layer must protect the perovskite layer as far as possible. Hydrophilic HTM will be more susceptible to moisture ingress than the hydrophobic ones. Even if the permeability to liquid water/moisture can also depend on other factors such as thin film porosity, it remains that hydrophobicity should play a key role in moisture resistance for films of similar smoothness and compactness. We performed water contact angle measurements on the PCz1 layers studied in this work. LiTFSI and tert butylpyridine were incorporated into the film for mimicking the condition in PSCs. PCz1 film exhibited an average contact angle value of $93.7 \pm 5.6^{\circ}$ which correspond to rather high hydrophobic properties compared to Spiro-OMeTAD $\left(70^{\circ}\right.$ ) (Figure S3 in ESI).[29] It has been demonstrated that such hydrophobic properties are extremely beneficial to PSC stability.[30] A low surface roughness is an important requirement to decrease the current losses in PSC and get a better contact with the counter-electrode. For this purpose, the film forming property of doped PCz1 was examined by atomic force microscopy (Figure S4 in ESI). The PCz1 film showed a uniform and smooth surface with a mean surface roughness values of $0.97 \mathrm{~nm}$. This low value should improve the contact with the perovskite layer and counter-electrode.

\section{Photovoltaic application}

PCz1 was then studied as HTMs using $\mathrm{Cs}_{0.08} \mathrm{FA}_{0.80} \mathrm{MA}_{0.12} \mathrm{~Pb}\left(\mathrm{I}_{0.88} \mathrm{Br}_{0.12}\right)_{3}$ perovskite as the absorber material which has proved to be highly efficient for PSC application.[31,32] The device structure employed was: Glass-FTO/cTiO $/ \mathrm{mpTiO}_{2} /$ perovskite/HTM/Au with $c \mathrm{TiO}_{2}$ a compact layer prepared by spray pyrolysis and $m p \mathrm{TiO}_{2}$ a mesoporous $\mathrm{TiO}_{2}$ layer prepared by spin coating.[33,34] As mentioned above, the $\mathrm{E}_{\mathrm{HOMO}}$ and ELUMO of PCz1 are close to that of Spiro-OMeTAD so PCz1 should be suitable and work as well as SpiroOMeTAD. The best cell J-V curves are displayed in Figure 3a and the $J-V$ curve parameters are gathered in Table 1. The initial performances of Spiro-OMeTAD cells were superior to those of the PCz1 cells. The former exhibited a better $V_{\text {oc }}$ and $J_{\text {sc }}$. Both cells had a rather large hysteresis between the reverse and the forward scan curves. This trend was observed for both the record cells and the averaged data (Table $\mathrm{S} 2$ in the ESI). Table 1 also report the $J$ - $V$ curve parameters after 7 weeks of aging (storage in the $\mathrm{N}_{2}$ filled glovebox). We remark that the efficiency of the Spiro-OMeTAD PSCs decreased during this period of time. On the other hand, the PCE of PCz1 cells increased significantly reaching a value of $18.04 \%$ which is slightly superior to the initial PCE of the Spiro-OMeTAD PSC. Aging reduces the hysteresis in the case of the Spiro-OMeTAD device, while this parameter was slightly enlarged in the case of the PCz1 cell. 
Nevertheless, some of us have shown recently that with the triple cation perovskite employed in this study, the systems have a slow response in time and that the steady-state PCE is close to the PCE determined in the reverse bias scan conditions.[31] Figure 3b compares the spectral response of the two kinds of cells. The external quantum efficiency (EQE) curves of fresh cells are very close in the visible and near infra-red regions. They reach high efficiency values, up to $85 \%$. The spectra present an edge at about $780 \mathrm{~nm}$ due to the bandgap of the employed perovskite (1.60 eV). The main difference is found in the UV region with PCz1 cells having lower EQE(\%) in the UV region which is related to the lower bandgap of PCz1 compared to Spiro-OMeTAD that could reduce the component due to the light reflection on the back electrode. Nevertheless, as the UV-component of the solar spectrum is very low, this feature is not detrimental for the performances and the photogenerated $\mathrm{J}_{\mathrm{sc}}$ is close for these two devices.

(a)

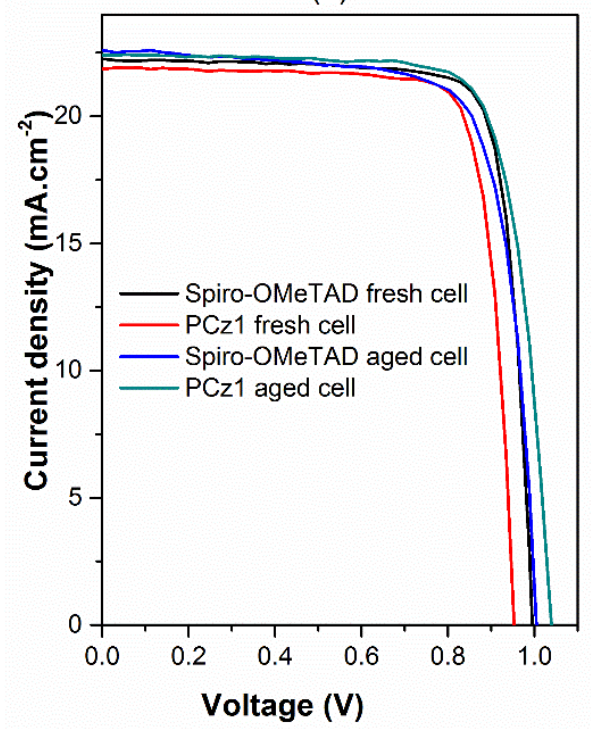

(b)

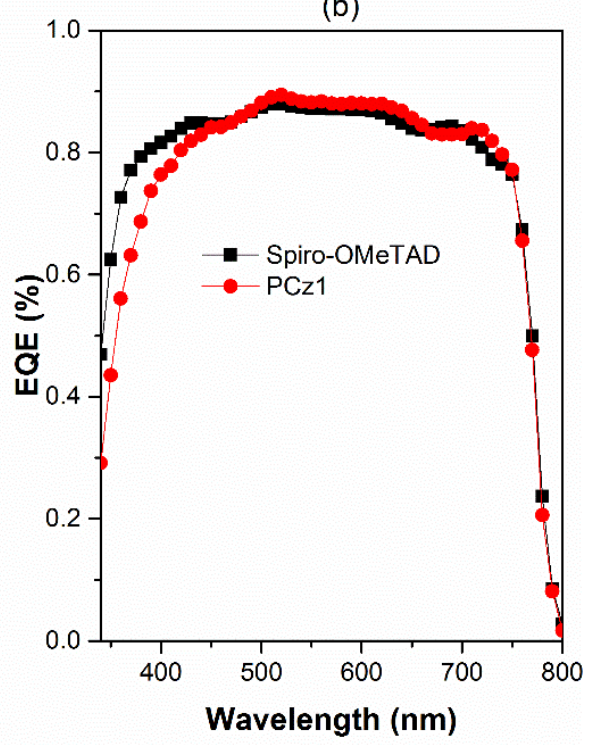

Figure 3. J-V and EQE curves of PSC devices (a) J-V curves of PCz1 and Spiro-OMeTAD cells, fresh and 7 weeks old; (b) EQE curves of PCz1 and Spiro-OMeTAD cells.

Table 1. Photovoltaic J-V parameters and PCE of best PSC cells prepared with PCz1 and Spiro-OMeTAD.

\begin{tabular}{|l|l|l|l|l|l|l|l|}
\hline & HTM & $\begin{array}{l}\text { Scan } \\
\text { direction }\end{array}$ & $\mathrm{V}_{\text {oc }}(\mathrm{V})$ & $\mathrm{J}_{\text {sc }}\left(\mathrm{mA} \cdot \mathrm{cm}^{-2}\right)$ & $\mathrm{FF}(\%)$ & PCE (\%) & HI (\%) \\
\hline \multirow{2}{*}{ Fresh cells } & $\begin{array}{l}\text { Spiro- } \\
\text { OMeTAD }\end{array}$ & Reverse & 0.99 & 22.25 & 81.20 & 17.94 & \multirow{2}{*}{26.9} \\
\cline { 2 - 7 } & Forward & 0.91 & 22.19 & 65.06 & 13.12 & \\
\cline { 2 - 8 } & PCz1 & Reverse & 0.95 & 21.88 & 80.87 & 16.84 & 30.1 \\
\hline
\end{tabular}




\begin{tabular}{|c|c|c|c|c|c|c|c|}
\hline & & Forward & 0.86 & 21.91 & 62.45 & 11.76 & \\
\hline \multirow{4}{*}{ Aged cells ${ }^{a}$} & \multirow{2}{*}{$\begin{array}{l}\text { Spiro- } \\
\text { OMeTAD }\end{array}$} & Reverse & 1.00 & 22.62 & 75.55 & 17.14 & \multirow{2}{*}{8.1} \\
\hline & & Forward & 1.02 & 22.55 & 68.79 & 15.76 & \\
\hline & \multirow{2}{*}{ PCz1 } & Reverse & 1.04 & 22.41 & 77.55 & 18.04 & \multirow{2}{*}{32.5} \\
\hline & & Forward & 0.97 & 22.44 & 55.70 & 12.17 & \\
\hline
\end{tabular}

a 7 weeks old cells. ${ }^{b}$ Hysteresis index defined as: $H I(\%)=\frac{P C E_{r e v}-P C E_{\text {for }}}{P C E_{\text {rev }}}$

The aging of the devices and the stabilization of the perovskite layers and interfaces are important parameters for the development of this technology. We have followed the evolution of the $J$ - $V$ curve parameters and PCE of solar cells prepared with the two different HTMs and stored in a $\mathrm{N}_{2}$ filled glovebox. The results are shown in Figure S5 in ESI. Clearly, the PCz1 cell presents a high stability with a PCE increase during the first weeks of aging. The improvement is mainly due to the enlargement of the $V_{o c}$ and, in a less extent, of the $J_{s c}$. On the other hand, the Spiro-OMeTAD PSCs present stable $V_{o c}$ and $J_{s c}$ parameters while the FF decreases slightly. Overall, during the first 60 days, the PCE of the PCz1 cell increased by $3 \%$ while it decreased by $5.5 \%$ for the Spiro-OMeTAD cell. It can be explained by the rather large size and flexibility of the oligomer HTM compared to the molecular one. The perovskite is covered by a denser layer and then better protected against moisture and other degrading agents. We can also suppose that the alternation of mesitylene and anisole in the PCz1 groups allows the close packing of the molecules by the low repulsion derived of fewer methoxy groups on the molecule. The latter can be partially confirmed by the low roughness values of the deposited layer. This is in good agreement with higher hydrophobic properties of the PCz1 film compared to the Spiro-OMeTAD one. The enlargement of the $\mathrm{V}_{\text {oc }}$ also suggests an improvement of the perovskite/PCz1 interface during the weeks following the cell preparation. Long-term stability and increment of the final PCE observed over time of 60 days is mainly due to the increase of final the voltage output from $0.98 \mathrm{~V}$ to $1.04 \mathrm{~V}$. In parallel a small reduction of the current output going from $22.88 \mathrm{~mA} . \mathrm{cm}^{-2}$ to $22.41 \mathrm{~mA} . \mathrm{cm}^{-2}$ is observed. Accordingly, the final PCE went from $16.84 \%$ to $18.04 \%$ for the forward scan. It represents an increment of $7 \%$ from the first PCE measurement. Many factors can contribute to the observed phenomena like the solid-state diffusion of the different components of HTL towards its self-stabilization.[35] It is evident that the stabilization of the PCz1 cell signifies an amelioration of the interphase contact derived of the HTL nature. 


\section{Conclusion}

In summary, novel carbazole-based oligomers were synthetized, characterized, and applied as hole transporting material in perovskite photovoltaic devices. The thermal, morphological, optical and electrochemical characterizations have shown that the PCz1 oligomer material is suitable for the role of HTM. Initial photovoltaic measurements gave a PCE of $16.84 \%$ which increased over 6 weeks to reach a value of $18.04 \%$. This PCE is superior to the PCE of the benchmark Spiro-OMeTAD cell. Moreover, the former has been shown much more stable than the latter. Current study is being conducted to optimize the synthesis of this family of molecules. More compounds of this family will be prepared in order to better understand the molecular structure/photovoltaic performance relationship of this series of carbazole derivatives.

\section{Materials and methods}

The detailed descriptions of materials synthesis, characterization, computational DFT calculation, perovskite-based photovoltaic device fabrication and measurements are given in the Electronic Supporting Information.

\section{Acknowledgements}

M.U. and D. M. acknowledges the Indonesian and Mexican governments for doctoral scholarships, respectively.

Conflicts of interest: the authors declare that there is no conflict of interest

\section{Reference}

1. H. S. Kim, I. H. Jang, N. Ahn, M. Choi, A. Guerrero, J. Bisquert, and N. G. Park, J. Phys. Chem. Lett. 6, 4633 (2015).

2. J. Y. Kim, G. Kwak, Y. C. Choi, D. H. Kim, and Y. S. Han, J. Ind. Eng. Chem. 73, 175 (2019).

3. P. K. Kung, M. H. Li, P. Y. Lin, Y. H. Chiang, C. R. Chan, T. F. Guo, and P. Chen, Adv. Mater. Interfaces 5, (2018).

4. X. Zhao and M. Wang, Mater. Today Energy 7, 208 (2018).

5. M. Ulfa, T. Zhu, F. Goubard, and T. Pauporté, J. Mater. Chem. A 6, 13350 (2018).

6. T.-T. Bui, M. Ulfa, F. Maschietto, A. Ottochian, M.-P. Nghiêm, I. Ciofini, F. Goubard, and T. Pauporté, Org. Electron. 60, 20 (2018).

7. M. Ulfa, T. Pauporte, T.-T. Bui, and F. Goubard, J. Phys. Chem. C 122, 11651 (2018). 
8. T.-T. Bui, S. K. Shah, X. Sallenave, M. Abbas, G. Sini, L. Hirsch, and F. Goubard, RSC Adv. 5, 49590 (2015).

9. T.-T. Bui, S. K. Shah, M. Abbas, X. Sallenave, G. Sini, L. Hirsch, and F. Goubard, ChemNanoMat 1, 203 (2015).

10. T. T. Bui, L. Beouch, X. Sallenave, and F. Goubard, Tetrahedron Lett. 54, 4277 (2013).

11. T.-T. Bui, F. Goubard, J. Troughton, and T. Watson, J. Mater. Sci. Mater. Electron. 28, 17551 (2017).

12. A.-N. Cho, H.-S. Kim, T.-T. Bui, X. Sallenave, F. Goubard, and N.-G. Park, RSC Adv. 6, 68553 (2016).

13. Y. Xue, Y. Wu, and Y. Li, J. Power Sources 344, 160 (2017).

14. M. Daskeviciene, S. Paek, Z. Wang, T. Malinauskas, G. Jokubauskaite, K. Rakstys, K. T. Cho, A. Magomedov, V. Jankauskas, S. Ahmad, H. J. Snaith, V. Getautis, and M. K. Nazeeruddin, Nano Energy 32, 551 (2017).

15. M.-D. Zhang, B.-H. Zheng, Q.-F. Zhuang, C.-Y. Huang, H. Cao, M.-D. Chen, and B. Wang, Dye. Pigment. 146, 589 (2017).

16. K. Rakstys, S. Paek, P. Gao, P. Gratia, T. Marszalek, G. Grancini, K. T. Cho, K. Genevicius, V. Jankauskas, W. Pisula, and M. K. Nazeeruddin, J. Mater. Chem. A 5, 7811 (2017).

17. Z. Chen, H. Li, X. Zheng, Q. Zhang, Z. Li, Y. Hao, and G. Fang, ChemSusChem 10, 3111 (2017).

18. X. Yin, L. Guan, J. Yu, D. Zhao, C. Wang, N. Shrestha, Y. Han, Q. An, J. Zhou, B. Zhou, Y. Yu, C. R. Grice, R. A. Awni, F. Zhang, J. Wang, R. J. Ellingson, Y. Yan, and W. Tang, Nano Energy 40, 163 (2017).

19. Š. Daškevičiū tė, N. Sakai, M. Franckevičius, M. Daškevičienė, A. Magomedov, V. Jankauskas, H. J. Snaith, and V. Getautis, Adv. Sci. 5, 1700811 (2018).

20. D. Li, J.-Y. Shao, Y. Li, Y. Li, L.-Y. Deng, Y.-W. Zhong, and Q. Meng, Chem. Commun. 54, 1651 (2018).

21. P. Gratia, A. Magomedov, T. Malinauskas, M. Daskeviciene, A. Abate, S. Ahmad, M. Grätzel, V. Getautis, and M. K. Nazeeruddin, Angew. Chemie - Int. Ed. 54, 11409 (2015).

22. A. Magomedov, S. Paek, P. Gratia, E. Kasparavicius, M. Daskeviciene, E. Kamarauskas, A. Gruodis, V. Jankauskas, K. Kantminiene, K. T. Cho, K. Rakstys, T. Malinauskas, V. Getautis, and M. K. Nazeeruddin, Adv. Funct. Mater. 28, 1704351 (2018).

23. C. Yin, J. Lu, Y. Xu, Y. Yun, K. Wang, J. Li, L. Jiang, J. Sun, A. D. Scully, F. Huang, J. Zhong, J. Wang, Y. B. Cheng, T. Qin, and W. Huang, Adv. Energy Mater. 8, 1 (2018).

24. N. Berton, R. Nakar, and B. Schmaltz, Synth. Met. 252, 91 (2019).

25. G. Sathiyan, E. K. T. Sivakumar, R. Ganesamoorthy, R. Thangamuthu, and P. Sakthivel, Tetrahedron Lett. 57, 243 (2016).

26. D. Magaldi, M. Ulfa, M. P. Nghiêm, G. Sini, F. Goubard, T. Pauporté, and T. T. Bui, J. Mater. Sci. 55, 4820 (2020). 27. Y. Ko, Y. Kim, C. Lee, Y. Kim, and Y. Jun, ACS Appl. Mater. Interfaces 10, 11633 (2018).

28. V. Mimaite, J. V. Grazulevicius, R. Laurinaviciute, D. Volyniuk, V. Jankauskas, and G. Sini, J. Mater. Chem. C 3, 11660 (2015).

29. Y. S. Kwon, J. Lim, H.-J. Yun, Y.-H. Kim, and T. Park, Energy Environ. Sci. 7, 1454 (2014). 
30. T. Leijtens, T. Giovenzana, S. N. Habisreutinger, J. S. Tinkham, N. K. Noel, B. A. Kamino, G. Sadoughi, A. Sellinger, and H. J. Snaith, ACS Appl. Mater. Interfaces 8, 5981 (2016).

31. T. Zhu, J. Su, F. Labat, I. Ciofini, and T. Pauporté, ACS Appl. Mater. Interfaces 12, 744 (2020).

32. P. Wang, M. Ulfa, and T. Pauporté, J. Phys. Chem. C 122, 1973 (2018).

33. P. Wang, Z. Shao, M. Ulfa, and T. Pauporté, J. Phys. Chem. C 121, 9131 (2017).

34. B. Viana, T. Pauporte, P. Wang, M. Ulfa, and Z. Shao, Proc. SPIE 10533, 105332R (2018).

35. F. Lamberti, T. Gatti, E. Cescon, R. Sorrentino, A. Rizzo, E. Menna, G. Meneghesso, M. Meneghetti, A. Petrozza, and L. Franco, Chem 5, 1806 (2019). 